\title{
Investigation of Tomato, Quince and Grapefruit Waste; Compositions and Functional Properties
}

\author{
Zeynep Aksit ${ }^{1}$ (D) Huseyin Genccelep ${ }^{2}$ (D) \\ ${ }^{1}$ Erzincan Binali Yildirim University, Department of Food Engineering, Erzincan, Turkey \\ ${ }^{2}$ Ondokuz Mayis University, Department of Food Engineering, Samsun, Turkey
}

\section{A B S T R ACT}

T he food industry constantly growing with increasing population and food diversity. In addition to production, the formation of food waste is also increasing. These wastes cause environmental pollution, economical problems and the loss of valuable chemical components. Tomato is used for tomato paste, sauce and other food production; especially the skin and seed part of tomato is waste. Grapefruit and quince have a significant amount of waste, especially in the beverage industry. The reuse of these wastes can reduce the exposure of solid waste, the environmental problem and the recovery of the bioactive components. In this study, some physicochemical, functional and thermal properties of quince, grapefruit and tomato waste were determined and their reuse potential was revealed. All three samples showed high hydration properties. According to the dietary fiber analysis, TDF of quince, grapefruit and tomato were $87.90 \%, 90.34 \%$, and $63.76 \%$ respectively. DTG and TGA chromatograms were obtained for the thermal decomposition of the samples. Tomato waste signaled lycopene and its derivatives as distinct from the other samples in the FT-IR spectrum. Based on the results of the study; the use of these wastes in many food products as hydrocolloid, filler, fat replacer is possible, also cost reduction may be possible with the recovery of these samples.

Keywords: Food waste, Tomato, Quince, Grapefruit, Dietary fiber, DTG, FT-IR

\author{
Article History: \\ Received: $2020 / 09 / 18$ \\ Accepted: 2021/01/17 \\ Online: 2021/03/31 \\ Correspondence to: Zeynep Akşit \\ zeynep.aksit@erzincan.edu.tr \\ Phone: +904462266666 , \\ Fax: +904462666665 .
}

\section{INTRODUCTION}

$\tau$ $n$ food factories, large quantities of food wastes are produced as a result of processing. Food waste causes adverse environmental problems including food shortages, prevention of food availability and releasing greenhouse gases. Therefore, the use of wastes in the production of new products has great importance in terms of human health, environmental pollution and the national economy [1-3]. These wastes include bioactive compounds such as polyphenols and essential oils along with dietary fibers that can be returned as valuable products that provide economic benefits for the food, cosmetic and pharmaceutical industries. Because consumers prefer natural and fiber-rich supplements; they are very valuable products for the food industry [4]. Dietary fibers include cellulose, lignin, hemicellulose, pectic substances, gums and other carbohydrates [5]. The insoluble fraction of dietary fiber is associated with bowel regulation, whereas the soluble fraction is associated with lower cholesterol levels and absorption of intestinal glucose [6]. In recent years, the food industry has focused on waste product evaluation, both to prevent the loss of these valuable substances and to prevent environmental problems caused by these wastes.

Quince fruit is difficult to consume due to its low moisture content, strong acidity, woody flesh, high amount of stone cells and astringent taste due to lignum development [7]. The high amount of lignin in the fruits limits their use in the food industry. The tendency of the quince to rot and turn to brown is a limiting factor in the long-term storage of this fruit [8]. Many studies have shown that quince jam and quince by-products are a good and inexpensive source for phenolic acids, antioxidants, and flavonoids [9].

Citrus processing, unlike other fruits; causes a small amount of the product but a significant amount of by-products during processing. The orange juice industry uses approximately $50 \%$ of the fruit and the re- 
maining 50\% waste part consists of shells, seeds, and albedo $[10,11]$. Citrus processing waste is a source of fiber, pectin, seed oil, essences, D-limonene, ethanol, ascorbic acid, soluble sugars, organic acids, amino acids, proteins, minerals, vitamins and flavonoids. They are generally used as a pectin source, animal feed, vinegar, molasses, fertilizer and citrus flour. However, apart from these limited uses, pulp waste is considered garbage and discarded $[10,11,13]$.

Tomato products rich in phytochemicals and flavonoids, so it is named as functional food and tomato processing waste is called as secondary raw material $[14,15]$. Tomato pulp; contains the skin, broken seeds and fruit flesh remaining from tomato juice extraction [16].

Within the scope of this study, the residual waste material from quince, grapefruit and tomato processing was obtained and the pulps were dried and ground. Various physical, chemical, and thermal analyses were performed to determine composition analysis and functional properties The characteristics of these three different waste products were determined and their reuse potential was investigated. It is aimed to reduce environmental pollution, to recover valuable components, to produce cheap and natural additives and to increase an option for product diversity.

\section{MATERIAL AND METHODS}

\section{Material}

Quince fruit was purchased from local market in Gümüşhane, Turkey. Quince waste obtained similar to quince juice processing factory; quince fruit pressed in the fruit juicer, the remaining solid waste washed several times under the tap water to reduce the sugar content, then kept in a hot water at $60^{\circ} \mathrm{C}$ for 3 minutes to reduce enzymatic browning $[17,18]$ and dried at $40^{\circ} \mathrm{C}$ in the oven for 24 hours. Grapefruit fruit was purchased from a local market in Gümüşhane, Turkey. Grapefruit waste is obtained as follows; the orange part of the grapefruit peels (the flavedo layer) was peeled off and the rest of the fruit was pressed in the juicer and the pulp portion was collected in the flask, then dried in a $40^{\circ} \mathrm{C}$ oven for 24 hours. Tomato waste was purchased from Limkon Gida Company (Adana, Turkey), the remaining part of the tomato paste production. Tomato waste was dried outdoor under the sun in Adana, at $38^{\circ} \mathrm{C}$ air temperature. All dried samples were milled and sieved through a $750 \mu$ sieve and kept at $4^{\circ} \mathrm{C}$ in a dark bottle until analyses. Fig. 1. represents quince, grapefruit, and tomato waste samples.

\section{Methods}

The moisture content, ash, $\mathrm{pH}$, crude protein, crude oil analyses were done as proximate analysis; water binding capacity (WBC), oil binding capacity (OBC), swelling ca-

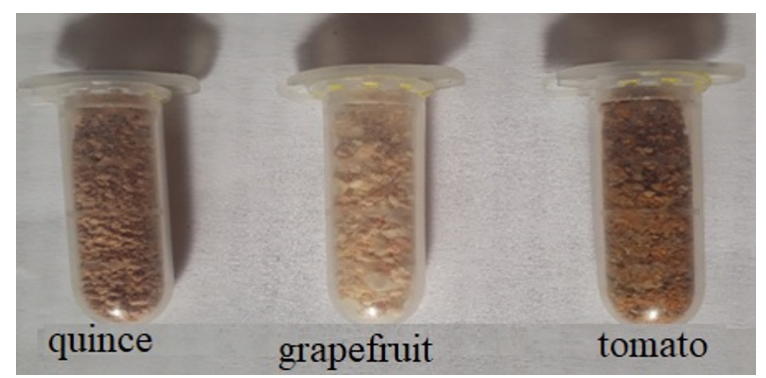

Figure 1. The image of the samples obtained.

pacity (SC) were done as hydration analyses. Water solubility index, dietary fiber analysis, thermogravimetric analyzes and FT-IR analyses of samples were also performed.

\section{pH and Proximate Analysis}

The ground samples were diluted with distilled water $(1 / 10 ; \mathrm{w} / \mathrm{v})$ and the $\mathrm{pH}$ values were measured by immersing the $\mathrm{pH}$ meter (Hanna Instruments HI2211) probe.

The obtained by-products were analyzed for proximate composition. Moisture, protein, fat, and ash analysis was carried out according to the AOAC standards. Moisture content was determined by drying samples at $105 \pm 1^{\circ} \mathrm{C}$ till reaching constant weights [19], crude protein content was determined by the Kjeldahl method, a factor of 6.25 was used for conversion of nitrogen to crude protein [20], fat content analyzed [21], and ash analysis done with burning samples at $550^{\circ} \mathrm{C}$ till white-grey color obtained [22].

\section{Water Binding Capacity (WBC)}

In order to determine the WBC of samples; $1 \mathrm{~g}$ of powder sample $\left(m_{1}\right)$ was placed in a centrifuge tube $\left(m_{2}\right) .20 \mathrm{~g}$ of water was added to $1 \mathrm{~g}$ powder sample at room temperature to dissolve the powder. The tube vortexed for $2 \mathrm{~min}$ then centrifuged for 20 minutes at $6000 \mathrm{rpm}$ at $4^{\circ} \mathrm{C}$. The clear supernatant was discarded and the remaining residue $\left(\mathrm{m}_{3}\right)$ was weighed [23].

$$
W B C=\left(m_{3}-m_{2}\right) / m_{1}
$$

\section{Oil Binding Capacity $(\mathrm{OBC})$}

In order to determine the OBC of samples; $1 \mathrm{~g}$ of grounded sample $\left(\mathrm{m}_{1}\right)$ was placed in the tared centrifuge tube and $20 \mathrm{~g}$ oil (corn oil $\rho: 0.9208 \mathrm{~g} / \mathrm{cm} 3)\left(\mathrm{m}_{2}\right)$ was added on. The vortexed tube was centrifuged at $4^{\circ} \mathrm{C}$ for 20 minutes at $6000 \mathrm{rpm}$. Then the supernatant was discarded and the remaining residue $\left(\mathrm{m}_{3}\right)$ was weighed [23]

$$
O B C=\left(m_{3}-m_{2}\right) / m_{1}
$$

\section{Swelling Capacity (SC)}

For SC analysis; firstly $1 \mathrm{~g}$ of powdered sample (m) was placed in the cylinder and the occupied volume $\left(\mathrm{V}_{1}\right)$ was 
measured. Then, $10 \mathrm{~mL}$ of water was added and agitation was carried out until a homogenous dispersion was obtained. The resulting dispersion is incubated for 24 hours at $25^{\circ} \mathrm{C}$ to allow the sample to fully bind the water. After 24 hours, the volume $\left(\mathrm{V}_{2}\right)$ of the wetted powder was measured and recorded.

$$
S C=\left(V_{2}-V_{1}\right) / m
$$

$\mathrm{SC}$ is swelling of $1 \mathrm{~g}$ sample with water and increased volume is expressed in $\mathrm{mL}$ [24].

\section{Dietary Fiber Analysis}

Total dietary fiber (TDF) and insoluble dietary fiber (IDF) contents of samples were determined by following AOAC-991.43 [25] and AACC-32-07 [26] standard methods and using a dietary fiber assay kit. Milled and weighed samples were transferred to beakers and they have first incubated with the heat resistant $\alpha$-amylase enzyme at $95-100^{\circ} \mathrm{C}$ to provide hydrolysis of starch to dextrins, then incubated with protease enzyme at $60^{\circ} \mathrm{C}$ and finally amyloglucosidase enzyme was completely hydrolyzed to glucose by dextrins. Obtained extracts were treated with ethanol to precipitate the soluble dietary fiber, filtered through Gooch crucibles (40-60 $\mu \mathrm{m}$ pores) and the weight of the dried sediment was recorded. Total dietary fiber amounts were calculated by deducting the amount of protein and ash from the sediment weight. Insoluble dietary fiber contents of the samples were also determined enzymatically-gravimetrically by modifying the precipitation and leaching steps applied in total dietary fiber analysis as recommended by these standard methods.

\section{Water Solubility Index (WSI)}

WSI was performed with a small modification in the method indicated by Yousif et al. [27]. 1\% aqueous solutions of the samples were taken into falcon tubes $\left(\mathrm{S}_{1}\right)$ and shook in a shaking water bath for 1 hour at a constant speed. The study was carried out at $10^{\circ} \mathrm{C}, 20^{\circ} \mathrm{C}, 30^{\circ} \mathrm{C}, 40^{\circ} \mathrm{C}, 50^{\circ} \mathrm{C}$, $60^{\circ} \mathrm{C}$ and $70^{\circ} \mathrm{C}$. The resulting mixture was centrifuged at $3000 \mathrm{~g}$ for 10 minutes. Then the supernatant was poured in a tared drying flask and dried at $105^{\circ} \mathrm{C}$ for 18 hours and measured $\left(\mathrm{S}_{2}\right)$.

$$
W S I=S_{2} / S_{1} \times 100
$$

\section{TGA \& DTG Analysis}

Thermal gravimetric analysis (TGA) was performed on a Perkin Elmer TGA7 analyzer and calibrated with calcium oxalate. $10 \mathrm{mg}$ samples were used, and the test was carried out at a temperature range between $35-500^{\circ} \mathrm{C}$ and a heating rate of $10^{\circ} \mathrm{C} / \mathrm{min}$ under a nitrogen atmosphere (nitrogen concentration 99.9\%). Derivative thermogravimetry (DTG) was obtained to determine the maximum weight loss rate.

\section{FT-IR Analysis}

Fourier-transform infrared spectroscopy (FT-IR) analysis was done by weighing $5 \mathrm{mg}$ of samples and mixing with 100 mg KBr. IR spectra were recorded between 4000-400 $\mathrm{cm}^{-1}$ under a 10-ton press at room temperature in Jasco 430 FT-IR spectrophotometer.

\section{Statistical Analysis}

SPSS V.22 packet program was used for statistical analyses. Duncan's new multiple range tests $(\mathrm{p}<0.05)$ was used to detect the differences among treatment means.

\section{RESULTS AND DISCUSSION}

\section{pH and Proximate Analysis}

The results of the $\mathrm{pH}$ and proximate analyses are shown in Table 1 . Ash \%, crude protein $\%$ and fat \% composition were given in wet basis. The lowest $\mathrm{pH}$ value was determined in the grapefruit waste as 4.15 . The $\mathrm{pH}$ of quince waste was 4.64 and the $\mathrm{pH}$ of tomato waste was 6.73 . The $\mathrm{pH}$ value of fresh grapefruit fruit is reported to be around 2.8-3.1 [28]. A researcher reported that quince fruit $\mathrm{pH}$ value was between 3.30-3.40 and the quince juice obtained from these fruits have the same $\mathrm{pH}$ value [29], and another researcher group reported that the $\mathrm{pH}$ value of the tomato juices was between 4.21-4.57 according to the growing conditions [30]. The high $\mathrm{pH}$ values of fresh fruits and vegetables can be attributed to the relationship between $\mathrm{pH}$ and acidity. Since some of the organic acids were removed with the removal of fruit and vegetable juice, the $\mathrm{pH}$ of the waste was higher than the fresh state in our results.

The moisture content of the samples was; $4.8 \%, 6.67 \%$, $7.4 \%$ for quince, grapefruit and tomato wastes respectively.

Table 1. $\mathrm{pH}$, proximate and hydration properties analysis results

\begin{tabular}{cccc}
\hline & Quince & Grapefruit & Tomato \\
\hline Moisture \% & $4.84 \pm 0.09^{c}$ & $6.67 \pm 0.12^{b}$ & $7.40 \pm 0.18^{a}$ \\
Ash \% & $0.98 \pm 0.02^{c}$ & $1.76 \pm 0.02^{b}$ & $5.11 \pm 0.01^{a}$ \\
Crude Protein \% & $1.41 \pm 0.41^{c}$ & $3.28 \pm 0.17^{b}$ & $13.60 \pm 0.43^{a}$ \\
Crude oil \% & $5.91 \pm 0.23^{c}$ & $13.17 \pm 0.82^{a}$ & $10.18 \pm 0.71^{b}$ \\
WBC (g/g) & $6.41 \pm 0.18^{b}$ & $13.09 \pm 0.01^{a}$ & $6.62 \pm 0.36^{b}$ \\
OBC $(g / g)$ & $2.93 \pm 0.03^{c}$ & $4.11 \pm 0.13^{a}$ & $3.47 \pm 0.02^{b}$ \\
SC $(\mathrm{mL} / \mathrm{g})$ & $2.70 \pm 0.14^{b}$ & $5.85 \pm 0.21^{a}$ & $2.00 \pm 0.2^{8 c}$ \\
& $87.90 \pm 0.99^{a}$ & $90.34 \pm 1.21^{a}$ & $63.76 \pm 2.18^{b}$ \\
TDF & & $4.15 \pm 0.06^{c}$ & $6.73 \pm 0.05^{a}$ \\
SDF & $5.22 \pm 0.29^{c}$ & $7.03 \pm 0.25^{a}$ & $6.10 \pm 0.23^{b}$ \\
Dietary Fiber & $82.68 \pm 1.46^{b}$ & $83.31 \pm 1.05^{b}$ & $57.66 \pm 1.62^{a}$ \\
\hline
\end{tabular}


Food wastes have high water content (80\%) and it is stated that the moisture content should be reduced to around 7\% to facilitate processing in the food industry and to obtain high dietary fiber-containing powder [10]. The ash contents were calculated as $0.98 \%, 1.76 \%$ and $5.11 \%$ in quince, grapefruit and tomato pulp, respectively. Ash content of tomato wastes was higher since samples taken from the tomato paste factory as a processing residue and this waste contains tomato stems, bunch and stalk. Crude protein amounts of the straws were determined as $1.41 \%, 3.28 \%$ and $13.60 \%$ for quince, grapefruit and tomato pulp, respectively. The percent of crude oil was determined as 5.91\%, 13.17\% and $10.18 \%$ in the same order. Dried and ground waste consists of different ratios of protein, lipid, ash, and fiber according to the type of harvested tomatoes [16]. Fresh fruit and vegetables have low percentages of protein, oil and ash than products and waste parts. All waste samples in our study have a higher amount of protein, oil and ash than the fresh state [31]. During processing (pressing, washing, peeling, heat treatment etc.) most components of fruit/vegetables are removed such as juice, skin (especially for citrus fruits) sugar, some other carbohydrates and micro components. This increases the protein, fat and ash ratio in the total mass.

\section{$\mathrm{WBC}, \mathrm{OBC}$ and SC Analysis}

WBC, OBC, and SC analysis give information about the hydration properties and hence the functional properties of the substances. The hydration properties of the dietary fiber indicate the ability to absorb water in the fiber mat rix. Fibers with potent hydration properties can increase faces weight, decrease the nutrient absorption rate from the intestine and increase the viscosity of foods in which it is added. Dietary fibers with high WBC can be used as functional components to prevent water release and to modify the viscosity and texture of some formulated foods. Dietary fibers with high OBC allow stabilization of high-fat food products and emulsions, prevent aroma migration and reduce fat loss during cooking [4, 14, 32].

WBC is defined as the amount of water held by a $1 \mathrm{~g}$ dry sample under specific conditions. According to the results of WBC, $1 \mathrm{~g}$ quince waste bound $6.41 \mathrm{~g}$ water, grapefruit waste bound $13.09 \mathrm{~g}$ water and tomato pulp bound $6.62 \mathrm{~g}$ water. Although quince and grapefruit wastes have closer TDF amount, grapefruit showed nearly two times WBC and $\mathrm{OBC}$ capacity than quince and tomato wastes. One of the reasons is; soluble part of the fiber is higher in the grapefruit sample; the other result may cause by grapefruit albedo content and structure of other components. The hydration properties of dietary fibers are related to the chemical structure of the polysaccharides in their compositions and other factors such as porosity, particle size, ionic form, $\mathrm{pH}$, temperature, ionic strength, type of ions in solution and stresses on the fibers. Water retention of dietary fiber is closely rela- ted to the source of dietary fiber [4].

OBC is expressed as the weight of $g$ of oil bound by 1 $\mathrm{g}$ of sample. According to the results of the OBC analysis; 1 gram of quince waste bound $2.93 \mathrm{~g}$ oil, the grapefruit pulp bound $4.11 \mathrm{~g}$ oil, and the tomato pulp bound $3.47 \mathrm{~g}$ oil. Grapefruit pulp has the highest WBC and OBC. Grapefruit TDF is attractive since it exhibited higher soluble/insoluble DF in lowering the absorption of lipids [33]. Quince and tomato samples have similar WBC and $\mathrm{OBC}$ values, only the quince sample was slightly higher. OBC of fibers is important in food applications; for example, the ability to increase the amount of feces by absorbing or binding bile acids is associated with plasma reduction and is effective in preventing fat loss during cooking. OBC depends on the overall density, thickness, surface properties of the fibers and hydrophobic nature of the fiber particle [14]. Insoluble fibers can bind up to 5 times their weight [32].

SC is the occupied volume of the known fiber weight under certain conditions. According to the results of the analysis, samples have a swelling capacity of $2.7 \mathrm{~mL} / \mathrm{g}, 5.85$ $\mathrm{mL} / \mathrm{g}$ and $2.0 \mathrm{~mL} / \mathrm{g}$ for quince, grapefruit, and tomato respectively. High SC is related to the amount of insoluble dietary fiber and is associated with a low amount of soluble fiber [14]. As shown in the dietary fiber content results; the insoluble fiber content of the grapefruit pulp is very high and it is expected that the $\mathrm{SC}$ is high. In the same table, the lowest amount of fiber in the insoluble fiber content is tomato waste, and this sample also has the lowest $\mathrm{SC}$ value. In a study, WBC of dietary fiber obtained from the orange juice is determined as $7.3 \mathrm{~g} / \mathrm{g}$ and $\mathrm{OBC}$ value $1.27 \mathrm{~g} / \mathrm{g}$ [34]. A researcher studied the tomato peel fiber and reported that the $\mathrm{WBC}$ was $6.76 \mathrm{~g} / \mathrm{g}$, OBC was $1.46 \mathrm{~g} / \mathrm{g}$ and the $\mathrm{SC}$ was $0.11 \mathrm{~mL} / \mathrm{g}[14]$.

\section{Dietary Fiber Analysis}

According to the results of the dietary fiber analysis, the grapefruit sample has the highest TDF at $90.34 \%$. The IDF ratio of this sample was determined as $83.31 \%$. The hydration properties of dietary fibers such as swelling and water binding capacity are related to IDF (32), so the grapefruit waste sample has the highest SC and WHC. TDF amount of quince waste was determined as $87.90 \%$ and IDF was $82.68 \%$. While tomato pulp has the lowest TDF ratio (63.76\%) compared to other types of pulp, it has also the lowest IDF ratio (57.66\%). The dietary fiber contents of the samples are shown in Table 1.

Thomas and Thibault [35]. reported that quince fruit contains $28-38 \%$ fiber due to its genotype. In a study, researchers determined the total fiber content of dried and ground orange juice by-products as $63.6 \%$ and the amount of soluble fiber as $17.4 \%$ [36]. Navarro-González et al., analy- 
zed tomato skin fiber and they found that the total dietary fiber amount was $84.16 \%$ and the amount of insoluble fiber as $71.82 \%$ [14]. Since the amount of fiber is higher in the skin, their TDF results higher than TDF of our tomato sample. The high content of cellulose and hemicellulose in vegetable skins increased the total and insoluble fiber ratio in their sample. Savadkoohi et al. reported that the total fiber content of tomato pulp residue from tomato paste manufacturing was about $40 \%$. Studies show that there are differences between the total fiber and soluble, insoluble fiber fractions of fruits, vegetables, and their residue [16]. These differences are thought to be caused by modifications in cell wall polysaccharides which may have both nutritional and functional effects [37].

\section{Water Solubility Index (WSI)}

Solubility is an important quality parameter and affects the functional properties of the powder in solid food systems, relates to the structure of polysaccharides; in the spine or the side chains regularly (insoluble) or irregular (soluble) settlements are effective. The presence of a substituent such as $\mathrm{COOH}$ or $\mathrm{SO}_{4}{ }^{2-}$ groups and increasing temperature increases the solubility [4]

According to the WSI analysis (shown in table 2); the solubility of samples was increased as the temperature increases for all three types of samples. The soluble fraction of the total dietary fiber is effective in the water solubility properties of the pulps. Grapefruit pulp with high soluble fiber content was more dissolved than other pulps. The tomato pulp with the lowest soluble pulp was identified as the least soluble pulp type. The water solubility of the fibers depends on the SDF amount $[32,38]$. Moreover, due to the positive effect of the temperature on the solubility, the solubility was increased by increasing the applied temperature for all samples.

\section{TGA and DTG Analysis}

Thermal analysis of foods gives information about food nature and modification during food processing. TGA

Table 2. WSI of samples

\begin{tabular}{|c|c|c|c|}
\hline Temperature & Quince (\%) & Grapefruit (\%) & Tomato (\%) \\
\hline $10^{\circ} \mathrm{C}$ & $9.2 \pm 1.70^{a b E}$ & $10.9 \pm 0.42^{a c}$ & $7.2 \pm 0.28^{b c}$ \\
\hline $20^{\circ} \mathrm{C}$ & $11.8 \pm 1.41^{a D E}$ & $10.7 \pm 0.99^{a b c}$ & $7.6 \pm 0.28^{b c}$ \\
\hline $30^{\circ} \mathrm{C}$ & $12.5 \pm 0.14^{a D}$ & $10.9 \pm 1.56^{a b c}$ & $7.7 \pm 0.85^{b c}$ \\
\hline $40^{\circ} \mathrm{C}$ & $25.0 \pm 1.13^{a c}$ & $21.4 \pm 3.96^{a b B}$ & $15.0 \pm 1.13^{6 B}$ \\
\hline $50^{\circ} \mathrm{C}$ & $28.9 \pm 1.27^{a B}$ & $25.6 \pm 0.85^{a B}$ & $15.2 \pm 1.41^{6 B}$ \\
\hline $60^{\circ} \mathrm{C}$ & $31.6 \pm 0.57^{a B}$ & $37.0 \pm 4.24^{a A}$ & $17.0 \pm 0.57^{b A B}$ \\
\hline $70^{\circ} \mathrm{C}$ & $36.1 \pm 1.56^{b A}$ & $41.9 \pm 0.71^{a A}$ & $18.4 \pm 1.98^{\mathrm{CA}}$ \\
\hline
\end{tabular}

analysis of quince, grapefruit and tomato waste are given in Fig. 2. In this analysis, the thermal behavior and degradation of the samples are revealed, DTG curves are given in Fig. 3. to see results better.

There was no significant weight loss at initial temperatures, all three samples started to lose weight after approximately $200^{\circ} \mathrm{C}$. Negligible weight losses observed at temperatures below $200^{\circ} \mathrm{C}$ are attributed to the removal of moisture and the onset of hydrolysis in polysaccharides [39]. All three samples have high fiber content and major components of crude fiber are cellulose, hemicellulose and lignin [40]. Generally, biomass pyrolysis is specifying these three main components. Lignocellulosic biomass is believed to be stable up to $200^{\circ} \mathrm{C}$ [41].

The quince pulp showed a large peak with a maximum decomposition point of $345^{\circ} \mathrm{C}$ adjacents to an unclear peak around $200^{\circ} \mathrm{C}$ to $310^{\circ} \mathrm{C}$. Cellulose has been reported to have higher thermal stability than hemicellulose and lignin, and lignin degradation begins at relatively low temperatures and progresses over a wide temperature range [42]. Thus, the peak onset was estimated to indicate degradation of the lignocellulosic structure, including hemicellulose, and the maximum point of the peak indicated cellulose. It is reported that the maximum decomposition temperature is higher in quince lignin samples in which sugar and phenolic compounds are removed, leading to more stable lignin structures after pretreatment [43].

Grapefruit pulp yielded two peaks that can be acceptable in a relatively narrow temperature range between $240^{\circ} \mathrm{C}$

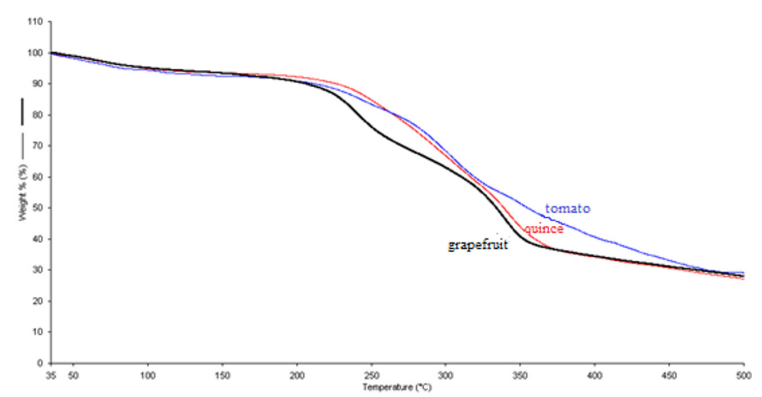

Figure 2.TGA analysis of samples

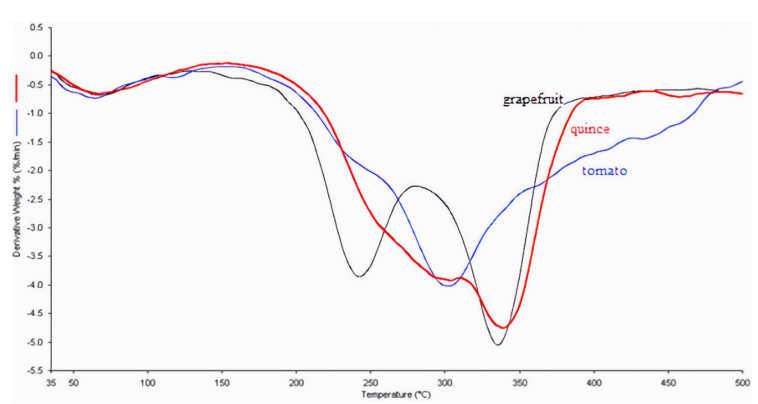

Figure 3. DTG analysis of samples 
and $340^{\circ} \mathrm{C}$. It was estimated that the first peak was hemicellulose and the second peak was cellulose, as hemicelluloses showed the least thermal stability in cellulosic compounds due to the presence of acetyl groups [42] while hemicelluloses typically decompose in the range of $160-360^{\circ} \mathrm{C}$, cellulose degrades at a higher temperature; $240-390^{\circ} \mathrm{C}$ [39]. In a study on orange waste, thermal decomposition was reported to occur in two stages; first hemicelluloses decompose between $125^{\circ} \mathrm{C}$ and $250^{\circ} \mathrm{C}$, second cellulose degradation between $250^{\circ} \mathrm{C}$ and $360^{\circ} \mathrm{C}$ was reported. It has been noted that simultaneous lignin decomposition is also present in the same temperature range [44].

The tomato pulp contains a high proportion of polysaccharides such as fiber and pectin [16]. Tomato waste yielded a wide peak starting at around $200^{\circ} \mathrm{C}$ peakings at $300^{\circ} \mathrm{C}$ and continuing to $500^{\circ} \mathrm{C}$. It is estimated that this peak formed over a wide temperature range is lignin which forms an important part of the tomato content but also contains lignin as well as cellulose and hemicellulose. There is a general idea that thermal decomposition peaks partially overlap hemicellulose, cellulose, and lignin [42]. For thermal decomposition analysis of tomato waste, it is reported that the DTG curves have a large number of peaks, indicating a quite complex pyrolysis. The complex thermal behavior of tomato samples can be illustrated by complex chemical composition characterized by the presence of various macro and micro components. The second and third peaks have been reported to results of thermal degradation of hemicelluloses and cellulose $[39,45]$.

\section{FT-IR Analysis}

IR spectra are a spectroscopic technique that provides information about the molecules or functional groups carried by molecules in a pure or mixed analyte. FT-IR spectra of quince, grapefruit and tomato pulp are given in Fig. 4. In the fingerprint region $\left(500-1500 \mathrm{~cm}^{-1}\right.$, specific for each item) there are differences in signal strength and observed signals. The range of $1600-1700 \mathrm{~cm}^{-1}$ is carbonyl bands; the signal of $\mathrm{C}=\mathrm{C}$ containing molecules in the samples. Especially in the spectrum of tomato waste at $1627 \mathrm{~cm}^{-1}$, the signal is more severe compared to other samples and it can be explained by conjugated $\mathrm{C}=\mathrm{C}$ bonds of lycopene and its derivatives in tomato waste. $1550-1650 \mathrm{~cm}^{-1}$ si gnals indicate free carboxyl groups and $1730-1745 \mathrm{~cm}^{-1}$ signals indicate esterified carboxyl groups. The signals observed in the range of $1700-1800 \mathrm{~cm}^{-1}$ for all three samples indicate the presence of molecules carrying the $\mathrm{C}=\mathrm{O}$ functional group (phenolics, terpenoids, steroids, organic acids, etc., bearing the carboxylic acid or carbonyl group). In a study on pectin isolated from grapefruit peels; it was reported that all pectin samples produced absorptions at $2930 \mathrm{~cm}^{-1}$ corresponded to the $\mathrm{C}-\mathrm{H}$ stretching of the $-\mathrm{CH},-\mathrm{CH}_{2}$ and $-\mathrm{CH}_{3}$ groups [46]
In a study on pectin isolated from tomato waste, FT-IR analysis showed a strong $\mathrm{OH}$ band due to the presence of carboxylic acids in the range of $3300-2500 \mathrm{~cm}^{-1}$ [47].

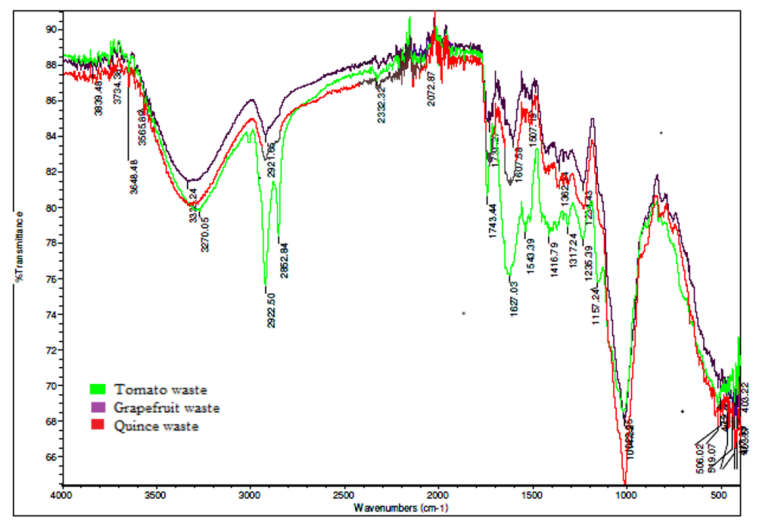

Figure 4. FT-IR chromatogram of samples

\section{CONCLUSION}

All over the world, food waste is increasing as the food industry develops. These wastes cause environmental pollution and economic problems as well as the loss of valuable food components. A large portion of these losses are fruit and vegetable wastes and contain a significant amount of valuable components. These by-products are rich in dietary fiber content has many benefits to human health. In this study; by-products of quince, grapefruit and tomato processing were evaluated and their contents and functional properties were determined. The lowest moisture content, ash, protein and fat content were determined in quince waste. The moisture, ash and protein content of tomato waste is higher than other pulp types. Concerning this result, the TDF amount of tomato waste is lower than other wastes. Quince, grapefruit and tomato wastes have high hydration properties, in terms of $\mathrm{WBC}, \mathrm{OBC}$ and $\mathrm{SC}$ and also all of them have high dietary fiber content. Grapefruit waste has higher TDF, SDF, and IDF, so this sample showed higher hydration properties than other samples, since its high albedo content. The use of such samples instead of other hydrocolloids in food formulations will be more economical due to waste product evaluation and is a natural supplement that will increase the reliability of the product and reduce the environmental problem of the operators. Also, high dietary fiber contents of these samples employ fat-reduced, sugar-reduced, functional products. Their use in the food industry such as dairy products, meat products, emulsions, etc. as hydrocolloid, filler, fat replacer is possible and has many advantages.

\section{ACKNOWLEDGEMENT}

There is no funder, researchers have done this work with their own means. 


\section{References}

1. Yağcı S, Altan A, Göğüş F, Maskan M. Gıda atıklarının alternatif kullanım alanları. Türkiye 9 Gıda Kongresi. 2006:499-502.

2. Jin Q, Yang L, Poe N, Huang $\mathrm{H}$. Integrated processing of plant-derived waste to produce value-added products based on the biorefinery concept. Trends in Food Science \& Technology. 2018.

3. Salihoglu G, Salihoglu NK, Ucaroglu S, Banar M. Food loss and waste management in Turkey. Bioresource technology. 2017.

4. Elleuch M, Bedigian D, Roiseux O, Besbes S, Blecker C, Attia H. Dietary fibre and fibre-rich by-products of food processing: Characterisation, technological functionality and commercial applications: A review. Food chemistry. 2011;124(2):411-21.

5. Köksel H, Özboy Ö. Besinsel lif analiz yöntemleri. Gıda/The Journal of Food. 1993;18(1).

6. Mehta N, Ahlawat S, Sharma D, Dabur R. Novel trends in development of dietary fiber rich meat products-a critical review. Journal of food science and technology. 2015;52(2):633-47.

7. Wojdyło A, Teleszko M, Oszmia ski J. Antioxidant property and storage stability of quince juice phenolic compounds. Food chemistry. 2014;152:261-70.

8. Yin $\mathrm{H}-\mathrm{S}$, Liu H-M, Liu Y-L. Structural Characterization of lignin in fruits and stalks of Chinese Quince. Molecules. 2017;22(6):890.

9. Jouki M, Yazdi FT, Mortazavi SA, Koocheki A. Physical, barrier and antioxidant properties of a novel plasticized edible film from quince seed mucilage. Int J Biol Macromol. 2013;62:500-7.

10. Fernandez-Lopez J, Fernandez-Gines J, Aleson-Carbonell L, Sendra E, Sayas-Barbera E, Perez-Alvarez J. Application of functional citrus by-products to meat products. Trends in Food Science \& Technology. 2004;15(3-4):176-85.

11. Fernandez Lopez J, Sendra Nadal E, Navarro C, Sayas E, Viuda Martos M, Alvarez JAP. Storage stability of a high dietary fibre powder from orange by products. International journal of food science \& technology. 2009;44(4):748-56.

12. Yoshida Y, Ueda M. Citrus juice waste as a potential source of dietary fiber. Journal of the Japanese Society for Horticultural Science. 1984;53(3):354-61.

13. Lario Y, Sendra E, Garcı-Pérez J, Fuentes C, Sayas-Barberá E, Fernández-López J, et al. Preparation of high dietary fiber powder from lemon juice by-products. Innovative Food Science \& Emerging Technologies. 2004;5(1):113-7.

14. Navarro-González I, García-Valverde V, GarcíaAlonso J, Periago MJ. Chemical profile, functional and antioxidant properties of tomato peel fiber. Food Res Int. 2011;44(5):1528-35.

15. Sönmez K, Ellialtıoğlu şş. Domates, karotenoidler ve bunları etkileyen faktörler üzerine bir inceleme. Derim. 2014;31(2):107-30.

16. Savadkoohi S, Hoogenkamp H, Shamsi K, Farahnaky A. Color, sensory and textural attributes of beef frankfurter, beef ham and meat-free sausage containing tomato pomace. Meat Sci. 2014;97(4):410-8.

17. Moon KM, Kwon E-B, Lee B, Kim CY. Recent trends in controlling the enzymatic browning of fruit and vegetable products. Molecules. 2020;25(12):2754.
18. Kumara B, Wijewardane R, Samarasinghe $Y$. The Effect of Anti-Browning Treatments for Fresh-Cut Guava Slices in Prevention of Browning during Dehydration. 2021.

19. AOAC. Official method of analysis Proximate Analysis and Calculations Moisture. Method 934.01. Association of Official Analytical Communities2006.

20. AOAC. Official method of analysis Proximate Analysis and Calculations Total Nitrogen or Crude Protein. Method 990.03. Association of Official Analytical communities 2006.

21. AOAC. Official method of analysis Proximate Analysis and Calculations Crude Fat. Method 920.39. association of Official Analytical communities2006.

22. AOAC. Official method of analysis Proximate Analysis and Calculations Ash. Method 942.05. Association of Official Analytical communities2006.

23. Gençcelep H, Sarıcaoğlu FT, Anıl M, Ağar B, Turhan S. The effect of starch modification and concentration on steadystate and dynamic rheology of meat emulsions. Food Hydrocolloid. 2015;48:135-48.

24. Lecumberri $E$, Mateos $R$, Izquierdo-Pulido $M$, Rupérez P, Goya L, Bravo L. Dietary fibre composition, antioxidant capacity and physico-chemical properties of a fibre-rich product from cocoa (Theobroma cacao L.). Food Chemistry. 2007;104(3):948-54.

25. AOAC. AOAC Official Method. Association of Official Agricultural Chemists, by the United States Department of Agriculture. 2000.

26. AACC. Aapproved Methods of the American Association of Cereal Chemists. 2004;11th edition.

27. Yousif E, Gadallah M, Sorour AM. Physico-chemical and rheological properties of modified corn starches and its effect on noodle quality. Annals of Agricultural Sciences. 2012;57(1):19-27.

28. Aylangan A, Başbayraktar V, Çetinkaya N, Denli E, Erçin $D$, Erel $Y$, et al. Narenciye grubu meyvelerde karantina amaçlı ışınlamanın gıda kalitesi ve hijyeni üzerine etkisinin araştırılması. Türkiye Atom Enerjisi Kurumu, Teknik rapor. 2010;TAEK TR-2010-2.

29. Güven S. Ayva Suyu ve Konsantratı Üzerinde bir Araştırma. GIda/The Journal of Food. 1982;7(6).

30. Şahin Ü, Özdeniz A, Zülkadir A, Alan R. Sera koşullarında damla sulama yöntemi ile sulanan domates (Lycopersicon esculentum Mill.) bitkisinde farklı yetiştirme ortamlarının verim, kalite ve bitki gelişmesine olan etkileri. Of Agriculture and Forestry. 1998;22:71-9.

31. http://www.turkomp.gov.tr/food [Internet]. Turkomp. 2021.

32. Burdurlu HS, Karadeniz F. Gıdalarda diyet lifinin önemi. Gıda Mühendisliği Dergisi. 2003;7(15):18-25.

33. Khalil MN, Farghal HH, Farag MA. Outgoing and potential trends of composition, health benefits, juice production and waste management of the multi-faceted Grapefruit Citrus paradisi: A comprehensive review for maximizing its value. Critical Reviews in Food Science and Nutrition. 2020:1-22.

34. Grigelmo-Miguel N, Martin-Belloso O. Characterization of dietary fiber from orange juice extraction. Food Res Int. 1998;31(5):355-61.

35. Thomas M, Thibault J-F. Cell-wall polysaccharides in the fruits of Japanese quince (Chaenomeles japonica): extraction and preliminary characterisation. Carbohyd Polym. 2002;49(3):345-55.

36. de Moraes Crizel T, Jablonski A, de Oliveira Rios A, Rech 
$\mathrm{R}$, Flores SH. Dietary fiber from orange byproducts as a potential fat replacer. LWT-Food Science and Technology. 2013;53(1):9-14.

37. Tosh SM, Yada S. Dietary fibres in pulse seeds and fractions: Characterization, functional attributes, and applications. Food Res Int. 2010;43(2):450-60.

38. Gan J, Peng G, Liu S, Hu X, Wang X, Guo S, et al. Comparison of structural, functional and in vitro digestion properties of bread incorporated with grapefruit peel soluble dietary fibers prepared by three microwave-assisted modifications. Food \& Function. 2020;11(7):6458-66.

39. Brachi P, Miccio F, Miccio M, Ruoppolo G. Pseudocomponent thermal decomposition kinetics of tomato peels via isoconversional methods. Fuel Processing Technology. 2016;154:243-50.

40. Monday R, Ephraim V, Julius N, Olaitan R, Idowu B. Effects of inclusion of processed grapefruit pulp on wheat flour biscuit. Journal of Food Technology. 2020;7(1):69-77.

41. Özsin G, Pütün AE. Kinetics and evolved gas analysis for pyrolysis of food processing wastes using TGA/MS/FT-IR. Waste Management. 2017;64:315-26.

42. Sebio-Puñal T, Naya S, López-Beceiro J, Tarrío-Saavedra $\mathrm{J}$, Artiaga R. Thermogravimetric analysis of wood, holocellulose, and lignin from five wood species. J Therm Anal Calorim. 2012;109(3):1163-7.

43. Qin Z, Zhang Z-G, Liu H-M, Qin G-Y, Wang X-D. Acetic acid lignins from Chinese quince fruit (Chaenomeles sinensis): effect of pretreatment on their structural features and antioxidant activities. RSC Advances. 2018;8(44):2492331.

44. Lopez-Velazquez M, Santes V, Balmaseda J, Torres-Garcia E. Pyrolysis of orange waste: a thermo-kinetic study. Journal of Analytical and Applied Pyrolysis. 2013;99:170-7.

45. Mangut V, Sabio E, Gañán J, González J, Ramiro A, González $C$, et al. Thermogravimetric study of the pyrolysis of biomass residues from tomato processing industry. Fuel Processing Technology. 2006;87(2):109-15.

46. Wang W, Wu X, Chantapakul T, Wang D, Zhang S, Ma X, et al. Acoustic cavitation assisted extraction of pectin from waste grapefruit peels: A green two-stage approach and its general mechanism. Food Res Int. 2017;102:101-10.

47. Grassino AN, Halambek J, Djakovic S, Brncic SR, Dent M, Grabaric Z. Utilization of tomato peel waste from canning factory as a potential source for pectin production and application as tin corrosion inhibitor. Food Hydrocolloid. 2016;52:265-74. 